\title{
METACOGNITIVE MONITORING ACCURACY AND LEARNING ACHIEVEMENT SUCCESS OF UNIVERSITY STUDENTS
}

\author{
Avhustiuk Maria \\ The National University of Ostroh Academy, \\ Ostroh, Ukraine, \\ maria.avgustiuk@gmail.com \\ ORCID: 0000-0001-8041-5078
}

Purpose. The paper is focused on the theoretical analysis of some theoretical and methodological aspects of the relationship between metacognitive monitoring accuracy and learning achievement success of university students. In particular, we highlight some approaches to the relation between metacognitive monitoring accuracy and learning achievement success that is a quite common problem in the university learning activity.

Methods. The theoretical and comparative methods of studying metacognitive monitoring accuracy and learning achievement success of university students have been used in the study. The necessity in studying some theoretical and methodological aspects of the notion has been caused by the impact of metacognitive monitoring accuracy on students' learning activities.

Results. The study aimed at revealing the role of metacognitive monitoring in the university learning activity, studying the extent to which changes in monitoring cause changes in the nature of the students' control over their own cognitive activities, specifying the nature of relationship between levels of confidence and students successes in learning, etc. A noteworthy finding is that students are generally overconfident in their self-assessments and this overconfidence effect is greatest for students of poorer abilities as they are doubly cursed: they lack knowledge of the material, and lack the awareness of the knowledge that they do and do not possess. The erroneous belief that information is understood when it is not is regarded as the illusion of knowing or overconfidence in knowing; the notion can be a significant obstacle to the effectiveness of the learning activities.

Conclusions. The results of the analysis found in the study can play an important role in the process of understanding the relationship between metacognitive monitoring accuracy and learning achievement success of university students.

Key words: metacognitive monitoring, accuracy, learning achievement success, confidence, students.

Августюк Марія. Точність метакогнітивного моніторингу та навчальна успішність студентів. Мема. У статті увагу зосереджено на аналізі деяких теоретичних та методологічних аспектів взаємозв'язку між точністю метакогні-

ISSN 2308-3743 (Online), ISSN 2227-1376 (Print)

(C) Avhustiuk M., 2020. Ця стаття відкритого доступу на умовах CC BY-NC 4.0 
тивного моніторингу й навчальною успішністю студентів університету. Зокрема, виокремлено підходи до розв'язання проблеми зв'язку між точністю метакогнітивного моніторингу та навчальною успішністю, що $є$ досить поширеною проблемою навчальної діяльності ЗВО.

Методи. У дослідженні використано теоретичні та порівняльні методи вивчення точності метакогнітивного моніторингу й навчальної успішності студентів університету. Необхідність вивчення деяких теоретичних і методологічних аспектів цього питання зумовлена впливом точності метакогнітивного моніторингу на навчальну діяльність студентів.

Результати. Мета дослідження - на основі теоретичного аналізу розкрити роль метакогнітивного моніторингу в навчальній успішності, проаналізувати, наскільки зміни в моніторингу спричиняють зміни в характері контролю студентів над власною пізнавальною діяльністю, установити характер взаємозв'язку між рівнями впевненості та успіхами студентів у навчанні тощо. Заслуговує на увагу висновок, що студенти, зазвичай, надмірно впевнені у своїх самооцінках, $\mathrm{i}$ цей ефект надмірної впевненості $є$ найбільшим у студентів із нижчим рівнем здібностей, оскільки вони подвійно обмануті: не знають матеріалу й не усвідомлюють також того, що вони не знають. Помилкове переконання, що інформація є зрозумілою тоді, коли це не так, розцінюється як ілюзія знання або надмірна впевненість у знанні; це поняття може бути суттєвою перешкодою для ефективності навчальної діяльності.

Висновки. Надбанням є те, що результати аналізу, виявлені в дослідженні, можуть зіграти важливу роль у процесі розуміння взаємозв'язку між точністю метакогнітивного моніторингу та навчальною успішністю студентів університету.

Ключові слова: метакогнітивний моніторинг, точність, навчальна успішність, упевненість, студенти.

Августюк Мария. Точность метакогнитивного мониторинга и учебная успеваемость студентов. Цель. В статье дается анализ некоторых теоретических и методологических аспектов взаимосвязи между точностью метакогнитивного мониторинга и учебной успеваемостью студентов университета. В частности, выделяются подходы к решению проблемы взаимосвязи между точностью метакогнитивного мониторинга и учебной успеваемостью, что является довольно распространенной проблемой учебной деятельности 3 ВО.

Meтоды. В исследовании используются теоретические и сравнительные методы изучения точности метакогнитивного мониторинга и учебной успеваемости студентов. Необходимость изучения некоторых теоретических и методологических аспектов этого вопроса объясняется влиянием точности метакогнитивного мониторинга на учебную деятельность студентов.

Pезультаты. Цель исследования - на основе теоретического анализа раскрыть роль метакогнитивного мониторинга в учебной успеваемости, проанализировать, насколько изменения в мониторинге вызывают изменения в характере контроля студентов над собственной познавательной деятельностью, 
установить характер взаимосвязи между уровнями уверенности и успехами студентов в обучении и т. д. Заслуживает внимания вывод, что студенты, как правило, чрезмерно уверены в своих самооценках, и этот эффект чрезмерной уверенности присущ для студентов с низким уровнем способностей, поскольку они вдвойне обмануты: не знают материала и не осознают также того, что они не знают. Ошибочное убеждение, что информация понятна тогда, когда это не так, расценивается как иллюзия знания или чрезмерная уверенность в знании; это понятие может быть существенным препятствием для эффективности учебной деятельности.

Bblводы. Достоянием является то, что результаты анализа, выявленные в исследовании, могут сыграть важную роль в процессе понимания взаимосвязи между точностью метакогнитивного мониторинга и учебной успеваемостью студентов университета.

Ключевые слова: метакогнитивный мониторинг, точность, учебная успеваемость, уверенность, студенты.

Introduction. Metacognitive monitoring is an important construct in the modern educational system. Consequently, the relation between metacognitive monitoring accuracy and learning achievement success is a quite common problem in the university learning activity. Foreign and Ukrainian researches show that both theoretical-methodological and empirical-practical aspects of the relation between metacognition and learning achievement success still remain controversial. In particular, there exist diverse data on the nature of the relationship between the learning achievement success of students and the accuracy of metacognitive monitoring. Moreover, there exist radically opposite theoretical approaches to the priority of such regulatory aspects of metacognition as metacognitive monitoring and metacognitive control. The question of the success of metacognitive monitoring accuracy in the laboratory experiments and in the educational context, in real situations of solving learning problems and assessing learning achievements remains unresolved.

An Overview of Recent Researches. Metacognitive monitoring is studied in a fairly wide range of foreign and Ukrainian researches. Various approaches have been proposed to the study of its main characteristics, structural components, types, the nature of the accuracy of metacognitive judgments of learning, and the sphere of influence on the learning process, etc.

To start with, in the sphere of revealing some theoretical and methodological aspects still only rare studies aim at solving the problem of the relationship between metacognitive monitoring accuracy and learning 
achievement success, especially in university students. Nietfeld, Cao, and Osborne (2005) examine the processes of metacognitive monitoring accuracy and student performance in a naturalistic setting. Isaakson and Fujita (2006) support the relationship of metacognitive knowledge monitoring to self-regulated learning and academic success. Miller and Geraci (2011) focus their attention on the reinterpreting overconfidence in lowperforming students. Savin and Fomin (2013) study relation of generalized and subject-specific metacognitive skills in solving learning problems. Stankov and Lee (2008) analyze the relationship between confidence and cognitive test performance. Some scientists study metacognitive monitoring accuracy in the context of such factors as rereading (the studies of Dunlosky \& Rawson; King, Zechmeister, \& Shaughnessy; Koriat \& Bjork, etc.) and generalization (the studies of Begg et al.; Koriat, etc.). Ukrainian scientists (Balashov, Kalamazh, Tkachuk, Pasichnyk, Voloshyna, etc.) also take into account the notion of metacognitive monitoring trying to figure out its relationship with the learning achievement success of university students. Thus, Balashov (2019) in detail studies psychological characteristics of metacognitive monitoring in learning activities of students. Tkachuk (2019) analyses influence of the accuracy of metacognitive monitoring on the success of earning activity, etc.

Analysis of psychological and pedagogical literature has also shown that metacognitive monitoring accuracy, as well as its relation to learning achievement success, cannot be studied apart from appropriate psychological and pedagogical conditions.

Thus, the aim of the paper is a theoretical framework of some theoretical and methodological aspects of the relationship between metacognitive monitoring accuracy and learning achievement success of university students.

Methods and Techniques of the Research. The theoretical and comparative methods of studying metacognitive monitoring accuracy and learning achievement success of university students have been used in the study. The necessity in studying some theoretical and methodological aspects of the notion has been caused by the impact of metacognitive monitoring accuracy on students' learning activities.

Results and Discussion. In the learning activity metacognitive monitoring is considered as the way of assessing students' cognitive activity and how these results direct to the solution of certain tasks, such as recalling answers, doing tests, and reading texts (Avhustiuk, Pasichnyk, \& Kalamazh, 
2018 , etc.). It is also considered as the assessment of the subjects' own knowledge, knowledge of cognitive strategies and knowledge of the conditions necessary for the application of the strategies that affect the learning process (the studies by Valdez, Koriat, etc.). In this extent metacognitive monitoring consists of various knowledge estimates that enable learners to engage in self-regulatory processes important for both the acquisition of knowledge and the monitoring of one's knowledge when engaged in such assessment (Valdez, 2013). Moreover, the notion is seen as explicit judgments aimed to promote the development of cognitive processes (Serra \& Metcalfe, 2009), etc. Thus, some studies (Winne \& Hadwin, 1998; Serra \& Metcalfe, 2009) show that students who know more about how to study and about how learning occurs (i.e., those who have higher levels of metacognitive knowledge) learn better than those with less metacognitive knowledge. For this reason, as Serra and Metcalfe (2009) state, educating students about how they learn and identifying both effective and ineffective learning strategies for them should not only improve the accuracy of their metacognitive judgements, but should improve their selfregulated learning as well.

Savin and Fomin (2013) propose to consider metacognitive monitoring in the learning process regardless to the extent how well students imagine the possibilities and limitations of their own knowledge in the process of solving learning problems, as well as how effective the strategies that they use to regulate their learning cognitive activities are. Consequently, the task of developing special learning procedures aimed at improving the quality of metacognitive activity of students is urgent (Avhustiuk, 2020).

There exist diverse theoretical approaches to the priority of such regulatory aspects of metacognition as metacognitive monitoring and metacognitive control. The processes of metacognitive monitoring as an important condition for the actualization of metacognitive control are determining factors in overall learning achievement success. In this aspect, the main attention is paid to the study of the extent to which changes in monitoring cause changes in the nature of the students' control over their own cognitive activities (Savin \& Fomin, 2013; etc.). If students cannot distinguish what they know and what they do not know, they are unlikely to be able to control their learning activities, or to choose the necessary strategies to achieve their goals (Fritzsche et al., 2012). In other words, effective metacognitive control is impossible without effective metacognitive monitoring. However, the problem is that metacognitive knowledge does 
not always lead to the choice of the optimal strategy or its change in solving certain learning and cognitive tasks.

A study conducted by Winne and some other scholars (Winne \& Hadwin, 1998, etc.) showed that those students who have learning difficulties approach the tasks differently than those with higher learning outcomes. Unsuccessful students process the material quickly and thoughtlessly, do not dwell on problematic aspects, do not notice when something remains unclear, and do not re-read difficult to understand parts. More successful students, on the other hand, tend to focus on these aspects, analyze and actively develop learning material. Supposedly, the indicators of the underachievers can be improved by teaching them to structure the material, to monitor what they do and do not understand, and to purposefully assist in the analysis (Avhustiuk, 2020).

Some psychological studies have shown that the level of intelligence affects a subjects' confidence in their judgments of metacognitive monitoring. As intellectual ability is considered to be a set of cognitive skills, such as the amount and easiness of cognitive tools available to the individual, and which include a certain set of inherent cognitive operations, the role of intellectual differences in metacognitive monitoring is significant (Avhustiuk, 2020).

Miller and Geraci (2011) expand the idea, proposed by Koriat et al., that the students, who study poorly and, accordingly, have low IQs, suffer twice, as they not only do not know, but also do not know that they do not know. The emphasis is that the subjects have a high degree of confidence in the predictions over the level of actual performance. The authors state that students are generally overconfident in their self-assessments and this overconfidence effect is greatest for students of poorer abilities. They are doubly cursed: they lack knowledge of the material, and lack the awareness of the knowledge that they do and do not possess. Altogether, the results of Miller and Geraci (2011) suggest that poor students are indeed unskilled but that they may have some awareness of their lack of metacognitive knowledge.

Consequently, studies by J. Bransford and others (Bransford et al., 1979) found that successful students know what they need to learn or do in order to achieve higher results. In addition, they are able to assess how well they understand and master the material, more often set up clarifying questions and are more effective in planning their learning activities. Initiative storage of information in memory with subsequent productive 
reproduction determines the active assimilation of the learning material. Conversely, the less successful ones are not able to do so; as a result, they more often have problems with the determining the task complexity, monitoring the level of performance awareness and the success of their actions.

A growing number of literature has investigated possible ways to generalize the relation between metacognitive judgments and student learning achievement success. Thus, there might be, according to Savin and Fomin (2013), such notions: 1) higher indicators of development of monitoring skills established with the help of questionnaires positively correlate with learning achievement success or with tests success as effective test taking depends on two important skills: selecting correct responses to test questions and monitoring one's performance accurately (Carvalho Filho, 2009; Schraw, 1997; Stankov \& Lee, 2008, etc.); 2) students who demonstrate more mature skills of metacognitive monitoring of their performance of knowledge tests receive higher scores, and, accordingly, show higher learning achievement success (Nietfeld, Cao, \& Osborne, 2005; Bol \& Hacker, 2001, etc.); 3) subjects who demonstrate not only lower performance of knowledge tests, but also lower learning achievement success, tend to overestimate their knowledge (Bol \& Hacker, 2001, etc.). Accordingly, the judgments of metacognitive monitoring are important components of the subjects' regulation of their own knowledge in learning activities.

The study by Nietfeld, Cao, and Osborne (2005) is one of the first studies to examine the processes of metacognitive monitoring accuracy and confidence in a naturalistic setting over a substantial period of time. In the study, students practiced metacognitive monitoring through the course of a whole semester. Then the changes in monitoring accuracy, judgment bias, and their relationship with academic performance were examined. In addition to a single global monitoring judgment on each classroom test students made local monitoring judgements for each test item. Results showed stability in monitoring accuracy across tests. And the accuracy was higher in their global judgements.

To specify, it should be noted that the nature of confidence is examined in relation to abilities, personality, and metacognition (Stankov \& Lee, 2008). The results of the studies indicate that confidence is a separate psychological trait, somewhere between ability and personality. It is also related to, but remains separate from, metacognition.

Schraw (1997) investigates the basis of students' confidence in their answers to test items. The results support the domain-general hypothesis 
stating that confidence judgments are related not only to performance on a particular test but also to confidence judgments and performance on unrelated tests. Moreover, the domain-general nature of confidence judgements may be attributable to generalized metacognitive knowledge.

Significantly, the accuracy of metacognitive monitoring is an important condition for students to be aware of their level of actual understanding of the learning material. The erroneous belief that information is understood when it is not is regarded as the illusion of knowing or overconfidence in knowing. The illusion of knowing as the mistake of metacognitive monitoring can be a significant obstacle to the effectiveness of the learning activities (the studies by Glenberg et al.), because the ignorance of when important information was missed can often slow down the learning process (the studies by Bradley, Glenberg, Epstein, Lindström, etc.). Overconfidence while learning poses a major threat to student learning and achievement. It can produce underachievement as inaccurate self-evaluations undermine students' learning and retention (Dunlosky \& Rawson, 2012). As a result, many receive unsatisfactory grades for the learning material they believe they knew well. Moreover, low grades may provoke sincere surprise of the learners.

The data of some studies (Nietfeld, Cao, \& Osborne, 2005; Isaacson \& Fujita, 2006; Pallier et al., 2002, etc.) prove that the students with higher levels of knowledge are less prone to overconfidence, and, therefore, are characterized by greater accuracy of metacognitive monitoring. They are more accurate at predicting their test results, more realistic in their goals, more likely to adjust their confidence in-line with their test results, and more effective in choosing test questions to which they know the answers (Isaacson \& Fujita, 2006). Thus, according to Pallier et al. (2002), personality traits and cognitive ability appear to play only a small role in determining the accuracy of students' self-assessments. In contrast, the subjects with lower levels of knowledge have more difficulties with the accuracy of metacognitive judgments and are more characterised with overconfidence in their judgments being unable to distinguish whether they answered correctly or not during their learning test (Miller \& Geraci, 2011).

Thus, common negative consequences of the inaccurate metacognitive monitoring can be as follows: inadequate self-assessment of learning outcomes; metacognitive incompetence in relation to one's own knowledge, skills, strategies, etc.; inability to assess the level of actual understanding of learning material; inability to distinguish between illusory and non-illusory 
knowledge; inefficient allocation of time and attention for studying the material, etc. (Avhustiuk, 2020).

Conclusions and Final Remarks. The research studies the peculiarities of the relation between metacognitive monitoring accuracy and learning achievement success. We have intended to describe some theoretical and methodological aspects of the relationship between the accuracy of metacognitive monitoring and learning achievement success of university students. We can assume that the results of the theoretical analysis found in the study play a significant role in the process of understanding this quite controversial relationship. Nevertheless, the studies of the nature of the relation between metacognitive monitoring accuracy factors and learning achievement success are on-going.

\section{References}

1. Балашов, Е. М. (2019). Психологічні особливості метакогнітивного моніторингу в навчальній діяльності студентів. Науковий вісник Херсонського державного університету. Серія: Психологічні науки, 4, 64-71. doi:10.32999/ ksu2312-3206/2019-4-8

2. Савин, Е. Ю., Фомин, А. Е. (2013). Когнитивная психология образования: аудитория как лабораторія. Психология в вузе, 3, 67-83.

3. Ткачук, О. В. (2019). Успішність навчальної діяльності та точність метакогнітивного моніторингу: теоретичний огляд проблеми. International scientific and practical conference «Prospects for the development of psychology as a science in EU countries and Ukraine»: зб. матеріалів. Варшава, 95-97.

4. Avhustiuk, M. M. (2020). Metacognitive monitoring accuracy and learning achievement success: Some theoretical and methodological aspects. Психологія та педагогіка: сучасні методики та інновачії, досвід практичного застосування: матеріали Міжнар. наук.-практ. конф., м. Львів, 23-24 жовт. 2020 р. (у друці).

5. Avhustiuk, M., Pasichnyk, I., \& Kalamazh, R. (2018). The illusion of knowing in metacognitive monitoring: Effects of the type of information and of personal, cognitive, metacognitive, and individual psychological characteristics. Europe's Journal of Psychology, 14(2), 317-341. doi:10.5964/ejop.v14i2.1418

6. Bol, L. \& Hacker, D. J. (2001). A comparison of the effects of practice tests and traditional review on performance and calibration. Journal of Experimental Education, 69(2), 133-151. doi: 10.1080/00220970109600653

7. Bransford, J. D., Franks, J. J., Morris, C. D., \& Stein, B. S. (1079). Some general constraints on learning and memory research. Cermak \& Craik, 331-354.

8. de Carvalho Filho, M. K. (2009). Confidence judgments in real classroom settings: Monitoring performance in different types of tests. International Journal of Psychology, 44(2), 93-108. doi:10.1080/00207590701436744

9. Dunlosky, J. \& Rawson, K. A. (2012). Overconfidence produces underachievement: Inaccurate self evaluations undermine students' learning and retention. Learning and Instruction, 22, 271-280. doi:10.1016/j.learninstruc.2011.08.003 
10. Fritzsche, E. S., Kröner, S., Dresel, M., Kopp, B, \& Martschinke, S. (2012). Confidence scores as measures of metacognitive monitoring in primary students? (Limited) Validity in Predicting Academic Achievement and the Mediating Role of Self-Concept. Journal of Educational Research Online, 4(2), 120-142.

11. Isaacson, R. M. \& Fujita, F. (2006). Metacognitive knowledge monitoring and self-regulated learning: Academic success and reflections on learning. Journal of the Scholarship of Teaching and Learning, 6(1), 39-55.

12. Miller, T. M. \& Geraci, L. (2011). Unskilled but aware: Reinterpreting overconfidence in low-performing students. Journal of Experimental Psychology: Learning, Memory, and Cognition. Online First Publication, 1-5. doi:10.1037/ a0021802

13. Nietfeld, J. L., Cao, L., \& Osborne, J. W. (2005). Metacognitive monitoring accuracy and student performance in the postsecondary classroom. The Journal of Experimental Education, 74(1), 7-28.

14. Pallier, G., Wilkinson, R., Danthiir, V., Kleitman, S., Knezevic, G., Stankov, L., \& Roberts, R. D. (2002). The role of individual differences in the accuracy of confidence judgments. The Journal of General Psychology, 129(3), 257-299. doi:10.1080/00221300209602099

15. Schraw, G. (1997). The effect of generalised metacognitive knowledge on test performance and confidence judgments. The Journal of Experimental Education, 65(2), 135-146. doi:10.1080/00220973.1997.9943788

16. Serra, M. J. \& Metcalfe, J. Effective implementation of metacognition. In D. J. Hacker, J. Dunlosky, A. C. Graesser (Eds.), Handbook of Metacognition and Education. New York: Routledge, 278-298.

17. Stankov, L. \& Lee, J. (2008). Confidence and cognitive test performance. Journal of Educational Psychology, 100(4), 961-976. doi:10.1037/a0012546

18. Valdez, A. (2013). Student metacognitive monitoring: Predicting test achievement from judgment accuracy. International Journal of Higher Education, 2(2), 141146. doi:10.5430/ijhe.v2n2p141

19. Winne, P. H., Hadwin, A. F. (1998). Studying as self-regulated learning: In D. J. Hacker, J. Dunlosky, A. C. Graesser (Eds.). Metacognition in Educational Theory and Practice, 277-304.

\section{References}

1. Balashov, E. M. (2019). Psykholohichni osoblyvosti metakohnityvnoho monitorynhu $\mathrm{v}$ navchalnii dialnosti studentiv [Psychological pecoliarities of metacognitive monitoring in learning activities of students]. Naukovyi Visnyk Khersonskoho Derzhavnoho Universytetu. Seria: Psykholohichni Nauky, 4, 64-71. DOI: https://doi.org/10.32999/ksu2312-3206/2019-4-8 (in Ukrainian).

2. Savin, E. Yu. \& Fomin, A. Ye. (2013). Kognitivnaia psikhologiia obrazovaniia: auditoria kak laboratoriia [Cognitive psychology of education: A classroom as a laboratory]. Psikhologiia v Vuze, 3, 67-83 (in Russian).

3. Tkachuk, O. V. (2019). Uspishnist navchalnoi dialnosti ta tochnist metakohnityvnoho monitorynhu: Teoretychnyi ohliad problemy [Learning success and accuracy 
of metacognitive monitoring: A theoretical overview of the problem]. Zbirnyk materialiv International scientific and practical conference "Prospects for the development of psychology as a science in EU countries and Ukraine», Warsaw, 9597 (in Ukrainian).

4. Avhustiuk, M. M. (2020). Metacognitive monitoring accuracy and learning achievement success: Some theoretical and methodological aspects. Psycholohiia ta Pedahohika: Suchasni metodyky ta innovatsii, dosvid praktychnoho zastosuvanniia. Materialy Mazhnarodnoi naukovo-praktychnoi konferentsii, Lviv, 23-24 October, 2020 (in press).

5. Avhustiuk, M., Pasichnyk, I., \& Kalamazh, R. (2018). The illusion of knowing in metacognitive monitoring: Effects of the type of information and of personal, cognitive, metacognitive, and individual psychological characteristics. Europe's Journal of Psychology, 14(2), 317-341. doi:10.5964/ejop.v14i2.1418

6. Bol, L. \& Hacker, D. J. (2001). A comparison of the effects of practice tests and traditional review on performance and calibration. Journal of Experimental Education, 69(2), 133-151. doi: 10.1080/00220970109600653

7. Bransford, J. D., Franks, J. J., Morris, C. D., \& Stein, B. S. (1979). Some general constraints on learning and memory research. Cermak \& Craik, 331-354.

8. de Carvalho Filho, M. K. (2009). Confidence judgments in real classroom settings: Monitoring performance in different types of tests. International Journal of Psychology, 44(2), 93-108. doi:10.1080/00207590701436744

9. Dunlosky, J. \& Rawson, K. A. (2012). Overconfidence produces underachievement: Inaccurate self evaluations undermine students' learning and retention. Learning and Instruction, 22, 271-280. doi:10.1016/j.learninstruc.2011.08.003

10. Fritzsche, E. S., Kröner, S., Dresel, M., Kopp, B, \& Martschinke, S. (2012). Confidence scores as measures of metacognitive monitoring in primary students? (Limited) Validity in Predicting Academic Achievement and the Mediating Role of Self-Concept. Journal of Educational Research Online, 4(2), 120-142.

11. Isaacson, R. M. \& Fujita, F. (2006). Metacognitive knowledge monitoring and self-regulated learning: Academic success and reflections on learning. Journal of the Scholarship of Teaching and Learning, 6(1), 39-55.

12. Miller, T. M. \& Geraci, L. (2011). Unskilled but aware: Reinterpreting overconfidence in low-performing students. Journal of Experimental Psychology: Learning, Memory, and Cognition. Online First Publication, 1-5. doi:10.1037/ a0021802

13. Nietfeld, J. L., Cao, L., \& Osborne, J. W. (2005). Metacognitive monitoring accuracy and student performance in the postsecondary classroom. The Journal of Experimental Education, 74(1), 7-28.

14. Pallier, G., Wilkinson, R., Danthiir, V., Kleitman, S., Knezevic, G., Stankov, L., \& Roberts, R. D. (2002). The role of individual differences in the accuracy of confidence judgments. The Journal of General Psychology, 129(3), 257-299. doi:10.1080/00221300209602099 
15. Schraw, G. (1997). The effect of generalised metacognitive knowledge on test performance and confidence judgments. The Journal of Experimental Education, 65(2), 135-146. doi:10.1080/00220973.1997.9943788

16. Serra, M. J. \& Metcalfe, J. Effective implementation of metacognition. In D. J. Hacker, J. Dunlosky, A. C. Graesser (Eds.), Handbook of Metacognition and Education. New York: Routledge, 278-298.

17. Stankov, L. \& Lee, J. (2008). Confidence and cognitive test performance. Journal of Educational Psychology, 100(4), 961-976. doi:10.1037/a0012546

18. Valdez, A. (2013). Student metacognitive monitoring: Predicting test achievement from judgment accuracy. International Journal of Higher Education, 2(2), 141146. doi:10.5430/ijhe.v2n2p141

19. Winne P. H., Hadwin A. F. Studying as self-regulated learning. In D. J. Hacker, J. Dunlosky, A. C. Graesser (Eds.), Metacognition in Educational Theory and Practice, 1998, 277-304.

Received: 06.10.2020

Accepted: 23.10.2020 